\title{
Climate Change in the North Pacific Using Ice-Rafted Detritus as a Climatic Indicator
}

\begin{abstract}
The variations in weight percent of the grain size fraction greater than $250 \mu$ in nine cores from the North Pacific were determined using sampling intervals of 5 to $20 \mathrm{~cm}$. Material in this size fraction is interpreted as transported by icebergs, and fluctuations are attributed to the waxing and waning of glaciers on the surrounding continents. At least eleven periods of increased ice rafting are detected in the cores during the time from 1.2 m.y. ago to the present, whereas only about four are identified from 1.2 m.y. to 2.5 m.y. B.P. The dating and time correlations are based on the magnetic stratigraphy, ash falls, and faunal extinctions.

The ice-rafted detritus indicates a cooling beginning about $1.2 \mathrm{~m} . y$. ago and becoming very intense between the Jaramillo event and the Brunhes-Matuyama boundary. This time may correspond to the initiation of mid-latitude glaciations of Europe and North America. At least six zones of ice-rafted sediment are present in the Brunhes normal polarity series. The correlations between these and the carbonate fluctuations of the central Pacific are good. Evidence for a marked interglacial ranging from about 460,000 to 530,000 yrs B.P. occurs within these cores. This interglacial may be worldwide in extent.
\end{abstract}

\section{INTRODUCTION}

The presence of ice-rafted detritus in deepsea sediment from mid- to high latitudes is a valuable climatic indicator and is probably the most direct evidence of continental glaciation to be found in deep-sea sediments. The temporal and spatial distribution of ice-rafted material in deep-sea sediments is a valuable clue to the history of the extent, intensity, and fluctuations of glaciations in the surrounding continental areas.

The stratigraphic distribution of ice-rafted material in deep-sea sediment cores has been studied in the North Atlantic and Antarctic
Oceans by Conolly and Ewing (1965a, 1965b). Their results indicate that several distinct zones containing high concentrations of ice-rafted detritus are present in the sediment of both oceans and may be interpreted as representing glacial stages. Later work in the northwest Pacific, which made use of the paleomagnetic reversal stratigraphy, identified six periods of ice rafting in the Brunhes normal polarity epoch $(700,000$ yrs ago) and the initiation of ice rafting at about 1.5 m.y. ago in this region (Conolly and Ewing, 1970). Hays and Opdyke (1967) dated the in ception of ice rafting in Southern Ocean as prior to 4.5 m.y. B.P.

\section{CORE LOCATIONS AND DESCRIPTIONS}

Nine deep-sea sediment cores from the North Pacific region between the Aleutian Islands and $45^{\circ} \mathrm{N}$. lat and between $165^{\circ} \mathrm{E}$. and $160^{\circ} \mathrm{W}$. long were studied (Fig. 1; Table 1). Cores V20-108, V20-109, and V20-119 were described and studied paleomagnetically by Ninkovich and others (1966); the paleomagnetic stratigraphy of the remaining cores was determined by Opdyke and Foster (1970). The cores range in length from 8.5 to $17 \mathrm{~m}$, and all but one (V21-171) penetrate to at least the Brunhes-Matuyama magnetic reversal boundary. All the cores except V20-119 consist of homogeneous, extensively burrowed brown muds broken only by one or more distinct ash

\begin{tabular}{|c|c|c|c|c|}
\hline Core & Latitude & Longitude & $\begin{array}{c}\text { Water } \\
\text { depth, m }\end{array}$ & $\begin{array}{c}\text { Core } \\
\text { length, } \mathrm{cm}\end{array}$ \\
\hline $\begin{array}{r}\text { V20-108 } \\
V 20-109 \\
V 20-119 \\
V 21-171 \\
V 21-172 \\
V 2]-173 \\
\text { RC10-782 } \\
\text { RC10-206 } \\
\text { RC1 } 1-771\end{array}$ & $\begin{array}{llll}42^{\circ} & 27^{\prime} & \mathrm{N} . \\
47^{\circ} & 19^{\prime} & \mathrm{N} . \\
45^{\circ} & 57^{\prime} & \mathrm{N} . \\
49^{\circ} & 53^{\prime} & \mathrm{N} . \\
47^{\circ} & 40^{\prime} & \mathrm{N} . \\
44^{\circ} & 22^{\prime} & \mathrm{N} . \\
45^{\circ} & 37^{\prime} & \mathrm{N} . \\
47^{\circ} & 73^{\prime} & \mathrm{N} . \\
46^{\circ} & 36.2^{\prime} & \mathrm{N} .\end{array}$ & 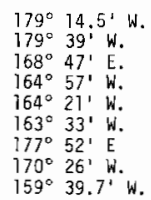 & $\begin{array}{l}5,625 \\
5,625 \\
2,739 \\
5,013 \\
5,198 \\
5,493 \\
5,561 \\
5,497 \\
5,167\end{array}$ & $\begin{array}{r}1,700 \\
1,460 \\
1,170 \\
850 \\
1,081 \\
1,218 \\
1,130 \\
1,152 \\
1,161\end{array}$ \\
\hline
\end{tabular}




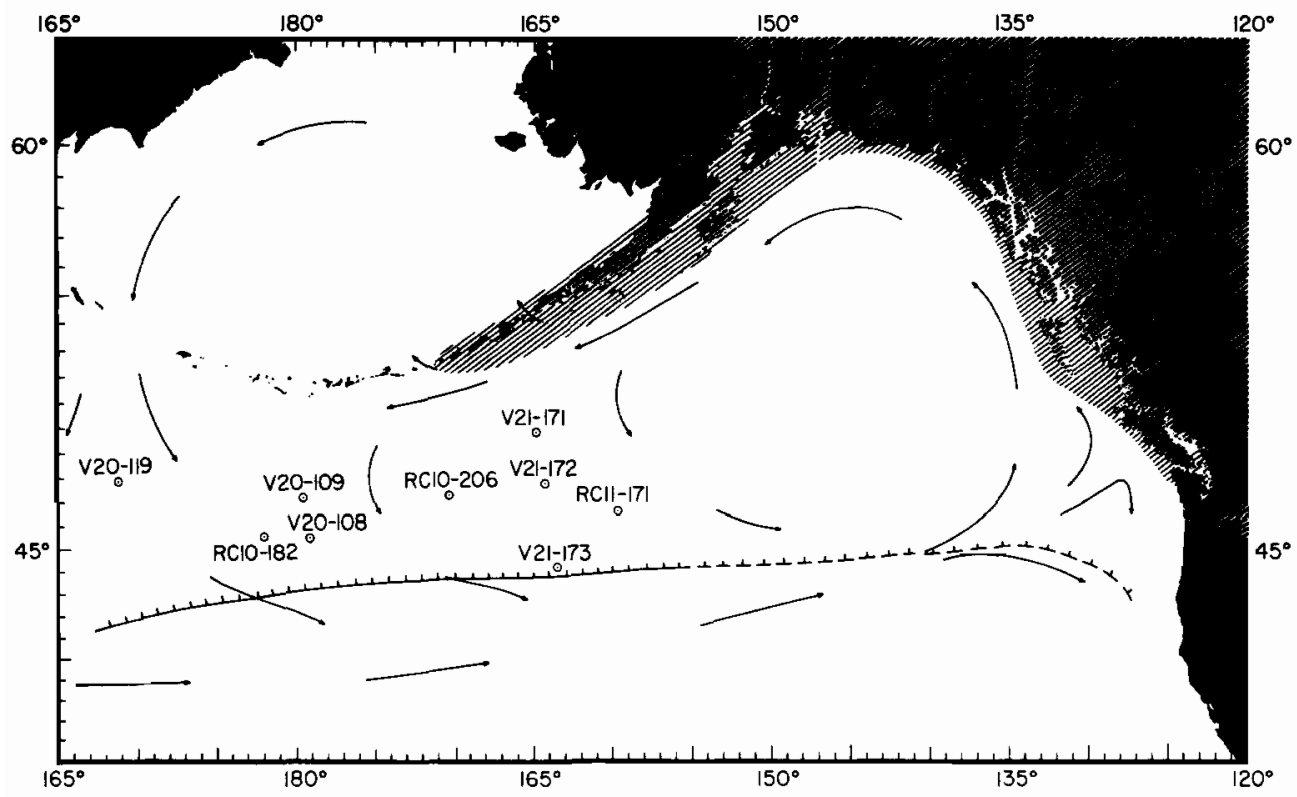

Figure 1. Location map of sediment cores in the North Pacific used in this paper. Present surface currents and extent of last glaciation are shown. Southern limit of

layers from 1 to $28 \mathrm{~cm}$ thick; V20-119 consists of alternating zones of sandy brown mud and tan-colored foraminiferal marls, becoming chalky toward the bottom. Carbonate content in all cores is absent except in V20-119, where it varies from zero to 60 percent.

No graded beds or other obvious evidence of turbidite deposition or erosion is present in any of the cores. Horn and others (1969) report this area to be free of turbidites because of the marginal Aleutian Trench which acts as a sediment trap. The only lithic break in the cores studied other than those associated with ash layers is a contact between chalky sediment below, and brown mud above, at $11 \mathrm{~m}$ in core V20-119.

The coarse fractions $(>74 \mu)$ vary from about zero to 20 percent by weight and contain diatoms and Radiolaria as the chief constituents. Foraminifera, primarily Globigerina pachyderma and Globigerina bulloides, are present in V20-119, and benthic agglutinated species are sporadically present in all cores. Other constituents include disseminated volcanic glass shards, some fresh but mostly altered pumice, and a variable amount of glacial marine material which at some levels constitutes up to three-quarters, but more commonly less than half, of the coarse fraction. The glacial marine component is a poorly sorted suite of clastic

glacial marine sediment (hachured line) determined from Conolly and Ewing (1970), Griggs and Kulm (1969), and this paper.

particles with pebbles and cobbles up to $70 \mathrm{~mm}$ in diameter (generally less than $1 \mathrm{~mm}$ in diameter; Fig. 2a). It consists of abundant, clear angular quartz grains, other mineral grains such as garnets and micas, subangular to faceted and polished basaltic and other igneous rock fragments, pieces of phyllite and other metamorphic rocks, and fragments of fine-grained quartz sandstone and greenish siltstone. A 20$\mathrm{mm}$ greenish siltstone fragment with pelecypod valves was found at $529 \mathrm{~cm}$ depth in core V21171. Several quartz grains were viewed under a scanning electron microscope and displayed surface features similar to those described by Krinsley and Margolis (1969) as diagnostic of glacial working (Fig. 2b, c).

\section{METHOD}

Dry weight percentages of insoluble material greater than $250 \mu$ in diameter were determined in samples spaced at approximately 10 $\mathrm{cm}$ intervals in the cores. Material greater than $250 \mu$ in diameter, where present in samples, consists of poorly sorted clastic grains. The smaller particles are mostly clear angular quartz while the larger grains are various kinds of rock fragments. The material in this size fraction of the samples is interpreted as being of ice-rafted origin because (a) Radiolaria and diatoms, which make up an appreciable component of 


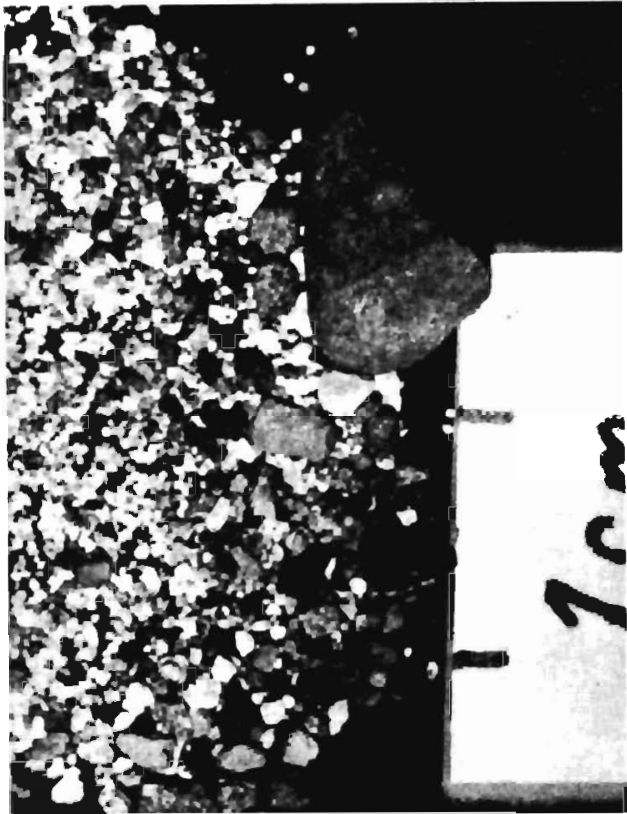

A.

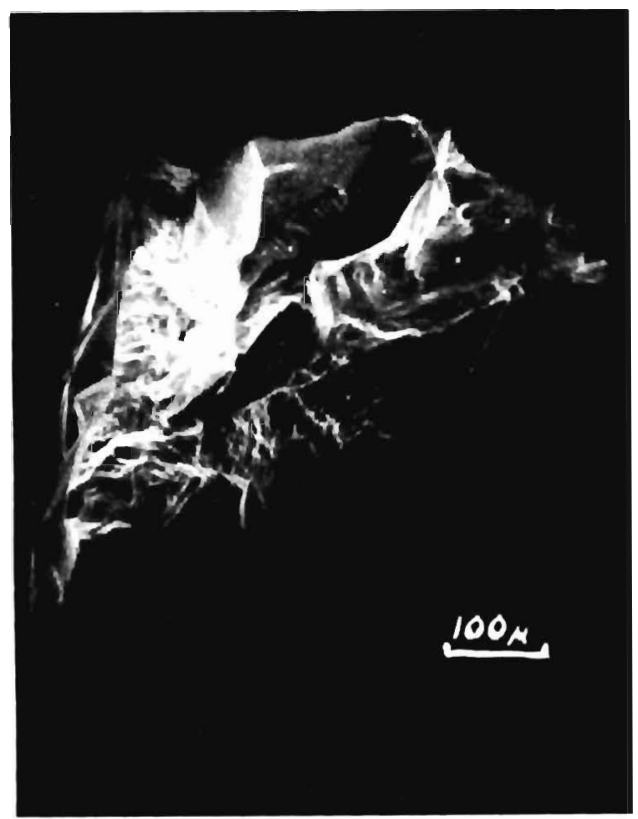

the coarse fraction $(>74 \mu$ ) and pose the greatest problem in quantifying the relative concentration of glacial marine sediment in these cores, are predominantly less than $250 \mu$ in diameter; (b) the presence of windblown

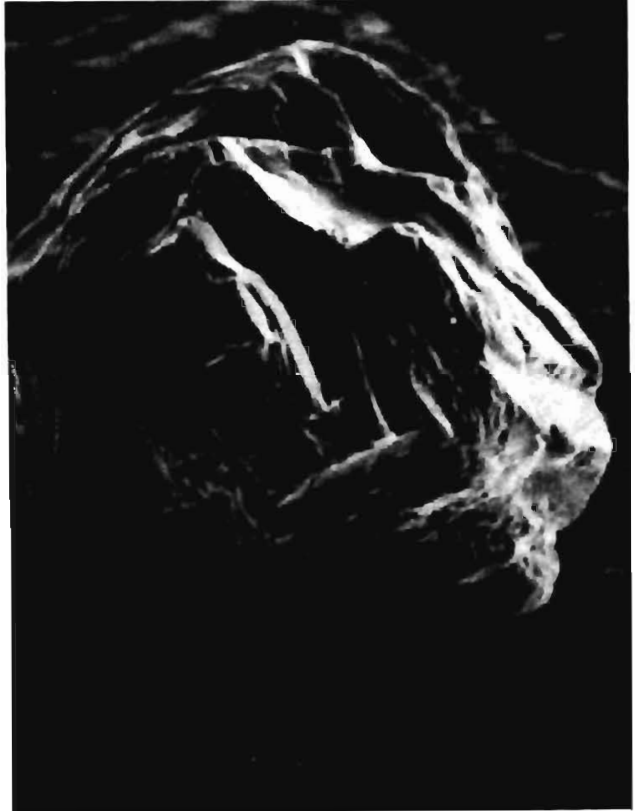

B.

C.

Figure 2. A. $>250 \mu$ fraction (V21-171, 649 cm) showing abundant quartz grains, rock fragments, and the poor sorting characteristic of glacial marine material in this area. B. Scanning electron photomicrograph (magnification $260 \times$ ) of quartz grain from RC10-182, $727 \mathrm{~cm}$. Note high relief, conchoidal fractures, smooth surface and lack of solution pits. C. Scanning electron photomicrograph (magnification $150 \times$ ) of quartz grain from V20-1 19, $1129 \mathrm{~cm}$. Similar surface features as (B) bur also with well-developed chatrer marks.

material larger than $250 \mu$ in diameter at any appreciable distance from source areas is unlikely (Bagnold, 1954), as evidenced by the fact that 99 percent of particles in volcanic ash layers in several cores from this area are less than $88 \mu$ in diameter (Ninkovich and others, 1966); (c) evidence of turbidity current deposits, the only other mechanism besides ice rafting capable of transporting significant amounts of coarse terrigenous material to this area, is lacking in these cores.

Because of the poorly sorted nature of glacial marine sediment, variations in the weight percentage of the $>250 \mu$ fraction can be used as an index to the variation in the amount of icerafted material in each sediment core. In addition to eliminating material less than $250 \mu$ in diameter from consideration in quantifying the relative abundance of glacial marine material, 
we have also ignored pebbles larger than $7 \mathrm{~mm}$ in diameter. This is because our index of ice rafting is readily biased by single large grains. The insoluble sediment size fraction that is $>$ $250 \mu$ and $<7,000 \mu$ in diameter in these cores is called the "glacial" fraction in this paper. This fraction is distributed through the sediment in several zones and is not concentrated in definite bands or laminations. This suggests that the size fraction is not a lag deposit due to winnowing by bottom currents.

In order to test the repeatability of the measured percentages, some of which are less than 0.5 percent, replicate sampling was carried out on V21-172 in a section of the core, where the $>250 \mu$ percentage was lowest (that is, less than 0.5 percent). The core was sampled three times at each horizon at nine levels between 312 and $334 \mathrm{~cm}$. The three samples taken from each horizon were necessarily smaller than the original samples and were therefore subject to a greater variability; also, the outside portion of the core was included which may also introduce error because of the dragging of sediment along the side of the core. Comparison of the individual values measured at the same level show close agreement. Similarly, the variation of the repeated values in this region $(n=27$, average $=.42$ percent, s.d. $=.23$ percent) is completely compatible with the original measurements which ranged from .17 percent to .41 percent. Since these sets of measurements were made in the region of lowest values, and consequently highest relative observational errors, they constitute a reasonably stringent test of the repeatability and reliability of the data.

\section{RESULTS}

Figure 3 shows the weight percentage of the "glacial" fraction of each core plotted against a uniform time scale. The basis for time-stratigraphic correlation between the cores is the paleomagnetic reversal stratigraphy (Ninkovich and others, 1966; Opdyke and Foster, 1970), tephrachronology, and the extinction horizons of two Radiolarian species, Druppatractus acquilonius and Stylatractus universus (Hays and Ninkovich, 1970; Ninkovich and others, 1966). Table 2 gives the levels of the various time horizons in the cores and the dates assigned to them in the construction of the time plots.

All cores but one (V21-171) penetrate to at least the Matuyama series, and two cores (V20109 and V21-173) reach sediments of the uppermost Gauss series. Core V21-171 can be
TABLE 2. AGES OF PALEOMAGNETIC REVERSALS BOUNDARIES, FAUNAL EXTINCTIONS, AND ASH LAYERS AND THEIR DEPTHS IN THE CORES STUDIED

\begin{tabular}{|c|c|c|c|c|c|c|c|c|c|c|}
\hline \multirow[b]{2}{*}{$\begin{array}{l}\text { Time } \\
\text { Horizon }\end{array}$} & \multicolumn{10}{|c|}{ Depth in core, $\mathrm{cm}$} \\
\hline & $\begin{array}{l}\text { Age } \\
\text { m.y. }\end{array}$ & $\frac{9}{\frac{9}{0}}$ & $\frac{m}{\frac{1}{N}}$ & $\frac{\pi}{\check{I}}$ & $\frac{N}{\frac{N}{N}}$ & $\begin{array}{l}\infty \\
\stackrel{ᄋ}{O} \\
\stackrel{1}{S}\end{array}$ & $\frac{ð}{0}$ & 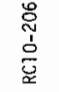 & $\begin{array}{l}\stackrel{a}{7} \\
\stackrel{\vdots}{\Xi}\end{array}$ & $\frac{5}{\frac{1}{2}}$ \\
\hline $\begin{array}{r}10 \\
\mathrm{Dr} \\
9 \\
\mathrm{St} \\
\mathrm{MB} \\
\mathrm{J}_{2} \\
\mathrm{~J}_{1} \\
6 \\
5 \\
4 \\
3 \\
0_{2} \\
01 \\
\mathrm{GM}\end{array}$ & $\begin{array}{l}.26 \\
.32 \\
.34 \\
.40 \\
.69 \\
.87 \\
.92 \\
1.16 \\
1.20 \\
1.39 \\
1.53 \\
1.71 \\
1.86 \\
2.43\end{array}$ & $\begin{array}{r}60 \\
120 \\
270 \\
337 \\
346 \\
545\end{array}$ & $\begin{array}{l}139 \\
180 \\
\\
220 \\
375 \\
460 \\
505 \\
\\
\\
674 \\
722 \\
780 \\
875 \\
1135\end{array}$ & $\begin{array}{l}200 \\
\\
260 \\
435 \\
535 \\
575 \\
671 \\
\\
817 \\
877 \\
955\end{array}$ & $\begin{array}{r}212 \\
260 \\
265 \\
360 \\
565 \\
705 \\
755 \\
850 \\
990 \\
9067\end{array}$ & $\begin{array}{r}365 \\
460 \\
792 \\
1005 \\
1070 \\
1290\end{array}$ & $\begin{array}{r}390 \\
480 \\
822 \\
1035 \\
1095\end{array}$ & $\begin{array}{r}320 \\
430 \\
775 \\
997 \\
1058\end{array}$ & $\begin{array}{l}275 \\
\\
355 \\
628 \\
720 \\
765\end{array}$ & $\begin{array}{l}605 \\
800 \\
822\end{array}$ \\
\hline
\end{tabular}

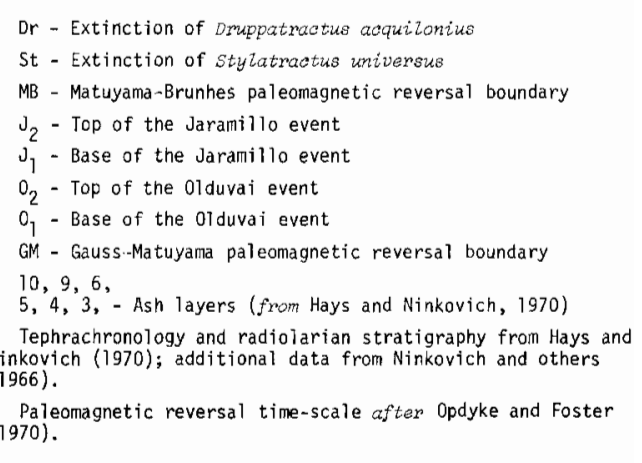

correlated with cores V21-172 and V21-173 by means of the extinction horizon of $D$. acquilonius and ash layers 9 and 10 (Fig. 3; Table 2). Core V20-109 is interpreted as missing about $1.5 \mathrm{~m}$ from its top because of the positions of the extinction levels of $D$. acquilonius and $S$. universus. The top of the core is apparently at about .22 m.y. ago (Fig. 3), assuming a constant sedimentation rate above the Brunhes-Matuyama boundary in the core.

Ice-rafted detritus is present intermittently throughout all the cores but is generally more abundant in the upper than the lower sections of the cores. An upward transition from less abundant to more abundant ice-rafted detritus occurs at about $1250 \mathrm{~cm}$ in V20-108; $700 \mathrm{~cm}$ in RC1 1-171; $550 \mathrm{~cm}$ in V20-109; and $600 \mathrm{~cm}$ in V21.173 (Fig. 3). It is not apparent in V21172. The average percentage of the glacial frac-

Figure 3. Weight percentage of the $>250 \mu$ fraction versus time for eight cores in the North Pacific. Correlations based on paleomagnetic reversal stratigraphy, extinction levels of $D$. acquilonius and $S$. universus, and tephrachronology (see Table 2). 


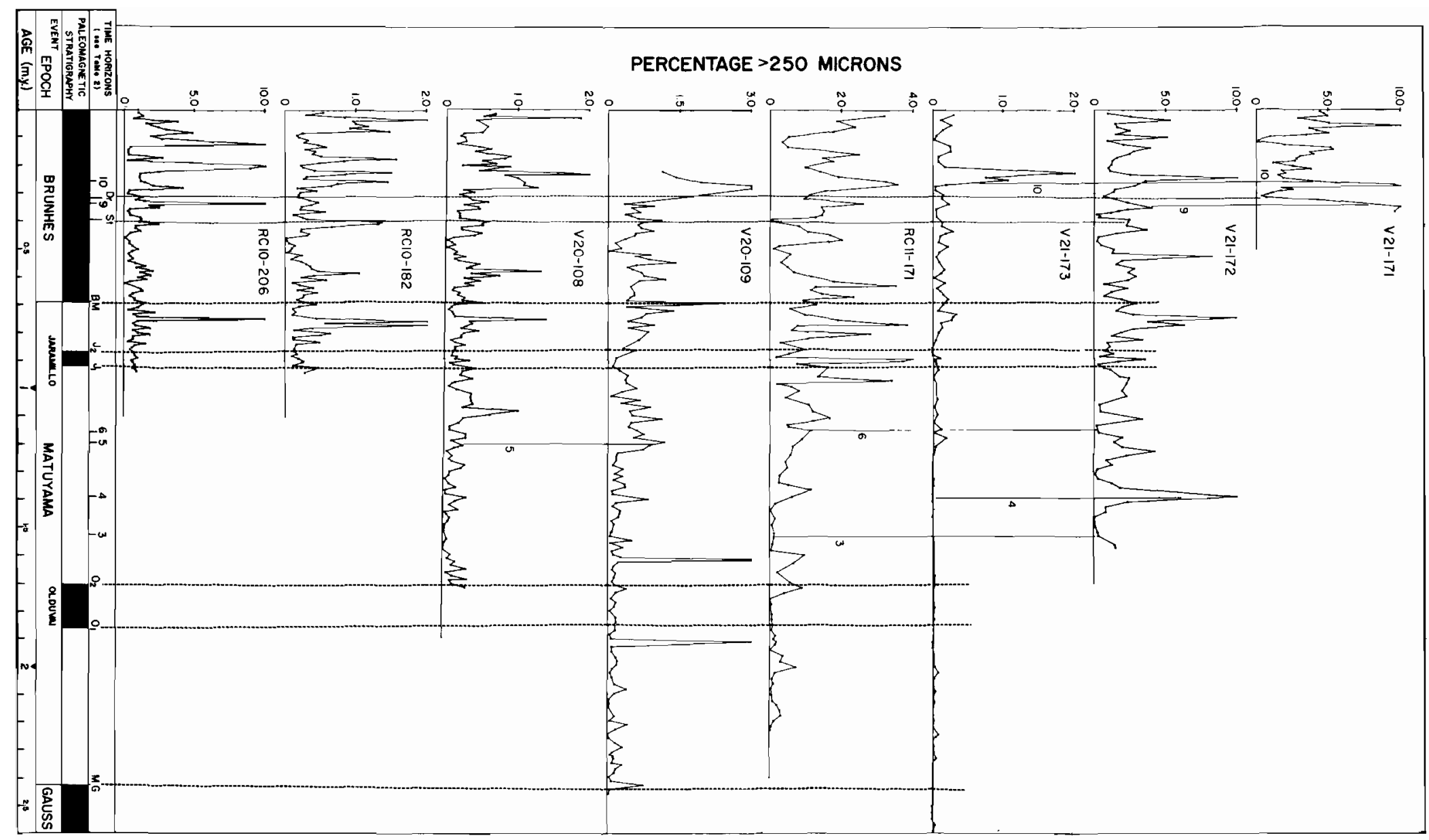


tion is at least three times greater in the upper sections than in the lower sections of these cores. Ice-rafted material of this sediment size is essentially absent below $600 \mathrm{~cm}$ in V21-173. The average age for this transition is about 1.2 m.y.

Not only is there an over-all higher concentration of glacial marine material in the upper (post-1.2 m.y. ago) sections of the cores, but zones containing relatively high percentages of ice-rafted material occur more frequently in this section. At least eleven periods of more intense ice rafting are represented in the past 1.2 m.y. section, seven of which occur in the Brunhes, whereas only about four are found in the section from $1.2 \mathrm{~m} . \mathrm{y}$. ago to the GaussMatuyama boundary ( $2.43 \mathrm{~m}$.y. ago).

Fluctuations in the percentage of the glacial fraction can be correlated from core to core with the use of magnetic stratigraphy, tephrachronology, and Radiolarian extinction horizons (Fig. 3). The extincrion level of $D$. acquilonius is found to be usually associated with low glacial fraction concentration (except in V20-109), while the extinction level of $S$. universus seems to be associated with high glacial fraction concentration (except in $\mathrm{RCl1}$ 171). A rather persistent zone, characterized by very low concentration of glacial marine material, is present in all cores and has an average extrapolated age of between $.46 \mathrm{~m}$.y. to .53 m.y. Table 3 summarizes the zones with high glacial concentration found in these cores and their extrapolated ages.

\section{INTERPRETATION}

This part of the North Pacific is presently devoid of iceberg activity, and substantial sea ice does not occur south of the Aleutian Islands (U. S. Hydrographic Office Charts, H. O. 550 , 1946). The general low concentration of the glacial fraction in the topmost sediment in these cores apparently corresponds to this most recent climatic situation in the area. It seems reasonable, then, to assume that zones in the cores containing relatively high concentration of glacial marine material correspond to periods of more intense glaciation in the source areas (presumably western North America, the Aleutians, and the Kamchatka peninsula). If this assumption is true, then the glacial fraction percentage curve for these cores may be used as some indication of the climatic regime in the area where zones of high glacial fraction concentration represent a more glaciated condition of the land areas.

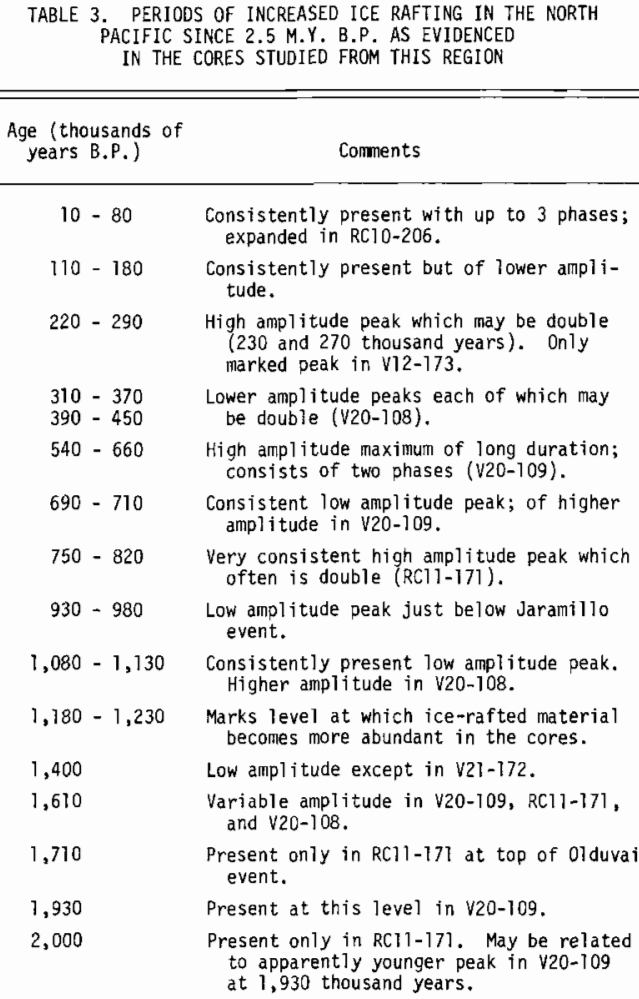

On this basis, we can infer that at least parts of the surrounding land areas were intermittently glaciated and supplied glacial marine material into the North Pacific basin since at least $2.5 \mathrm{~m} . y$. ago, which is the extrapolated age of the oldest level penetrated in this suite of cores. This is to be expected in the light of recent studies which suggest late Cenozoic glaciation of Alaska as early as 10 m.y. ago (Denton and Armstrong, 1969). It would be difficult to correlate the beginning of the Pleistocene with the onset of glaciation in this region. Moreover, no significant change in the abundance of glacial detritus occurs across the Olduvai event (Fig. 3), which has been correlated with the Plio-Pleistocene boundary (Berggren and others, 1967). A transition, however, does occur in several cores somewhat later (at about 1.2 m.y. ago), across which there is an upward increase in abundance of ice-rafted material. The character of the transition to cooler conditions in the North Pacific may be inferred from the change in coiling ratios of populations of $G$. pacbyderma in V20-119 (Fig. 4). Coiling direction of $G$. pacbyderma has been used as a climatic indicator (Bandy, 1960; Ericson, 1959), wherein dominantly counter-clock- 


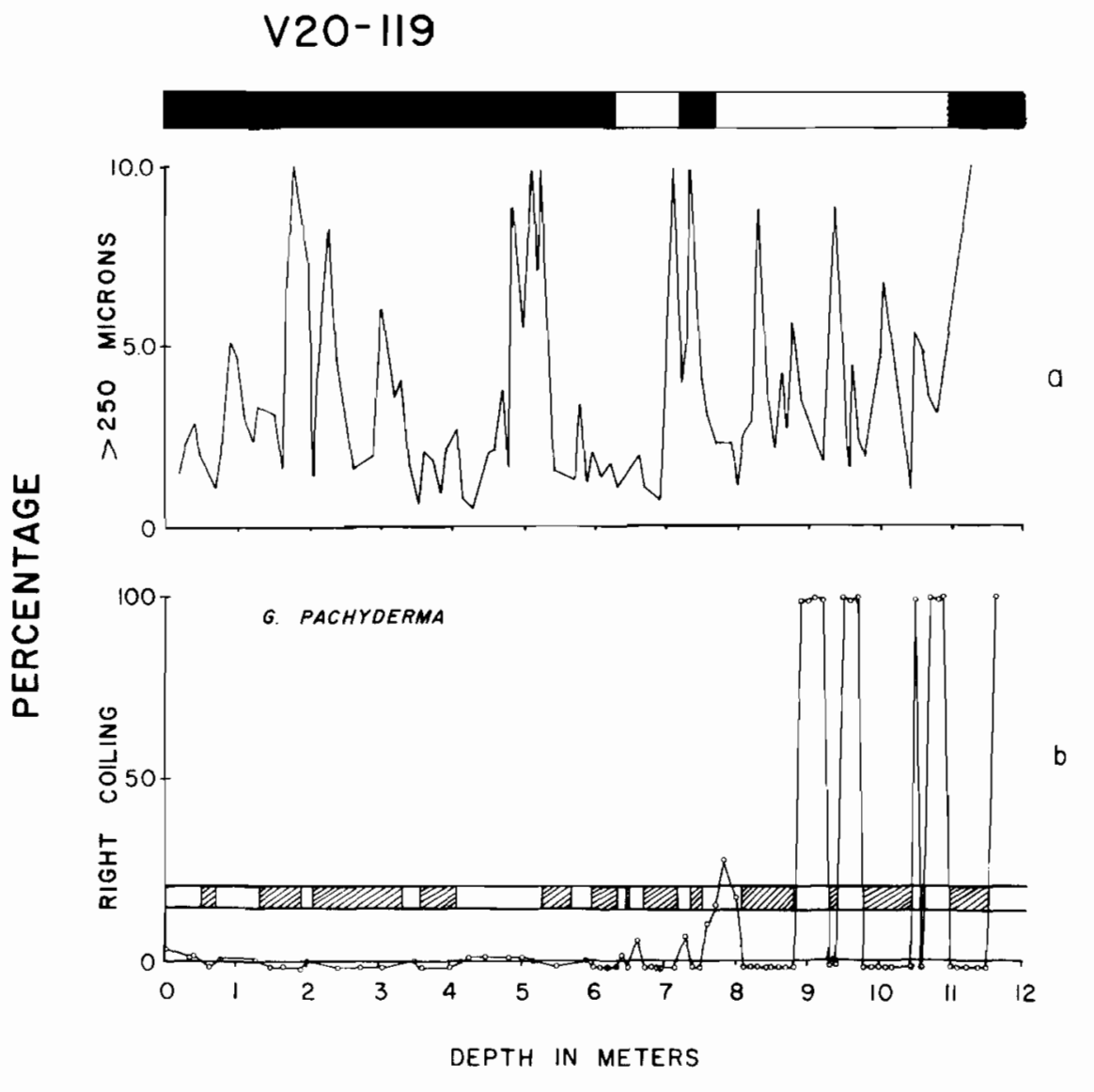

Figure 4. Paleomagnetic stratigraphy of V20-119 (Ninkovich and others, 1966). a. Plot of weight percentage of the $>250 \mu$ fraction in V20-119. b. Percentage of right-coiling $G$. pacbyderma in V20-119 based on counts

wise coiling population represents cold conditions and dominantly clockwise coiling population represents more temperate conditions. The successive decrease in the percentage of right coiling $G$. pacbyderma from $880 \mathrm{~cm}$ to $650 \mathrm{~cm}$ during interglacials in V20-119 indicates a general southward shift of colder water masses through this interval. This general cooling trend is superimposed over glacial fluctuations that were operative since at least 2.5 m.y. ago (Fig. 5). Hence, even in the section below $880 \mathrm{~cm}$ where $G$. pachyderma is over 98-percent right coiling (where present), substantial amounts of ice-rafted material are present in several zones $(930$ to $940 \mathrm{~cm} ; 975$ to $1045 \mathrm{~cm}$; $1060 \mathrm{~cm}$ ) The cooling occurs across the Jara- of 300 individuals per sample. Samples in which no $G$. pacbyderma are found are plotted below the abscissa and the barren zones are indicated by diagonal hachuring.

millo event and may have started as early as 1.1 m.y. ago $(880 \mathrm{~cm})$. Donahue's (1970) determination of diatom Td values (ratio of warm to cold water diatom species) in V20-108 also can be interpreted as showing a cooling near the Jaramillo event (Fig. 6).

The evidence from the distribution of icerafted material, coiling direction changes of $G$. pacbyderma (this paper), and diatom population changes (Donahue, 1970), suggest that the North Pacific experienced a significant cooling of its surface waters with a coincident, or slightly earlier, increase in the intensity and frequency of glaciation of the surrounding land masses. Judging from the coiling direction of $G$. pachyderma in V20-119, the surface waters of at 


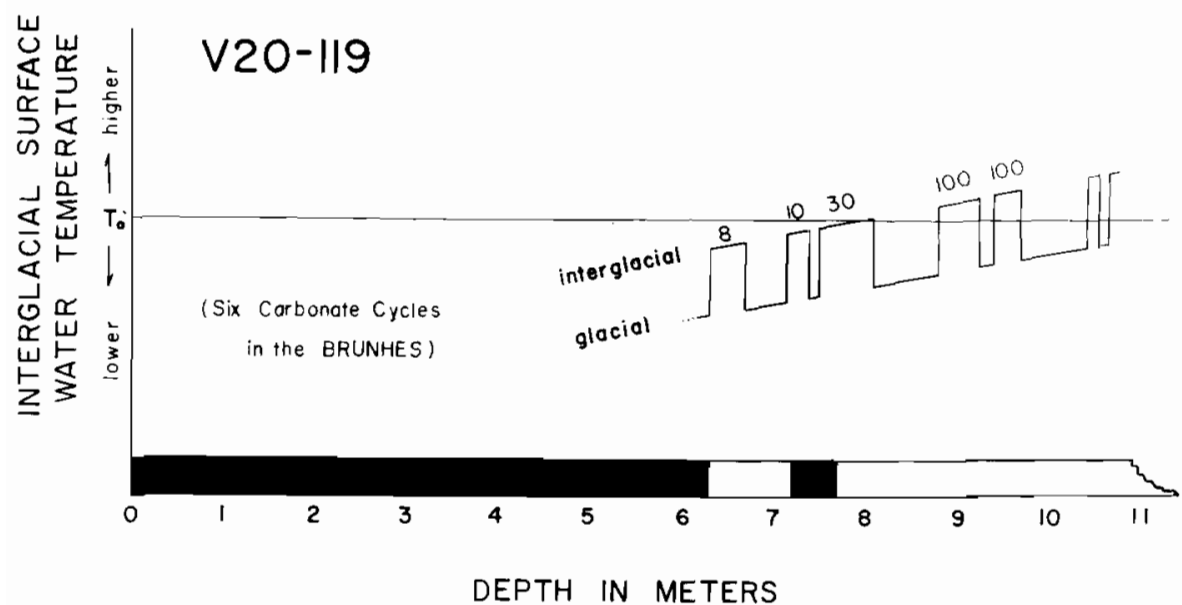

Figure 5. Interpretation of cooling of North Pacific waters across the Jaramillo event based on coiling ratios of $G$. pacbyderma in V20-119. Temperature, $\mathrm{T}_{\mathrm{o}}$, separating dominantly left-coiling from right-coiling $G$. pacbyderma may be similar to the April $7.2^{\circ} \mathrm{C}$ surface temperature isotherm determined in the North Atlantic (Ericson, 1959). Graph shows successive lowering of sur-

least this part of the Pacific have not warmed since the Jaramillo event to temperatures represented by dominantly right coiling $G$. $p a$ cbyderma prior to that time. Late Pleistocene cold cycles in California (Hallian) have been related to the Brunhes and uppermost Matuyama magnetic epochs and are preceded by a generally temperate climate (Wheelerian of California; Bandy and Casey, 1969). The paleontology of JOIDES Site 36 taken off the coast of California suggests a severe climatic deterioration caused by the onset of the Pleistocene glacial climate just below the Jaramillo event (Olson and Goll, 1970). This correlates well in time with the climatic history derived from this study of the North Pacific.

Evidence for a marked cooling in the midPleistocene has been found in other parts of the world ocean. The relevant evidence for such cooling is: (a) an upward increase in concentration of carbonate and coincident decrease in abundance of the tropical species Spheroidinella debiscens in the equatorial Pacific from about the Brunhes-Matuyama boundary (Hays and others, 1969); (b) marked increase in abundance of temperate foraminiferal species at a level within the Jaramillo event in the southern North Atlantic (Berggren and others, 1967); (c) a change in the sedimentary pattern in the eastern North Atlantic from about 1.0 m.y. ago (Needham and others, 1969); (d) a change in the diatom flora near the base of the Brunhes face water temperature during interglacials superimposed over glacial fluctuations. Temperature decrease across Jaramillo event may or may not have been in operation prior to $10 \mathrm{~m}$ or after $6 \mathrm{~m}$ in depth in V20-119. Numbers over interglacials indicate percentage rightcoiling $G$. pacbyderma.

in the South Atlantic (L. Burckle, 1970, personal commun.); (e) and the change in the radiolarian population near the Brunhes-Matuyama boundary in the Antarctic Ocean (Hays and Opdyke, 1967). It is apparent that the climatic deterioration which occurred somewhere between 1.2 m.y. and .7 m.y. ago (BrunhesMatuyama boundary) was a global phenomenon, although the cooling seemed to have occurred earlier in the northern hemisphere (Jaramillo event) than the southern hemisphere (base of Brunhes). This cooling may mark the inception of mid-latitude continental glaciation in the Pleistocene.

\section{COMPARISON WITH OTHER CLIMATIC SEQUENCES}

Pleistocene climatic sequences have been determined from deep-sea sediment cores from various oceans. Widespread use of absolute dating techniques, including magnetic reversal stratigraphy, permits a valid comparison to be made of the various sequences. There seems to be agreement that there were six to eight major fluctuations in the climate within the Brunhes.

Donahue (1970) shows eight cold intervals in the Brunhes in core V20-108 in the North Pacific. Although the glacial fraction percentage curve for this core shows a similar number of fluctuations, the time correlation between the two methods is rough at best (Fig. 6). There is apparently some lag in the response of the 


\section{V20-108}
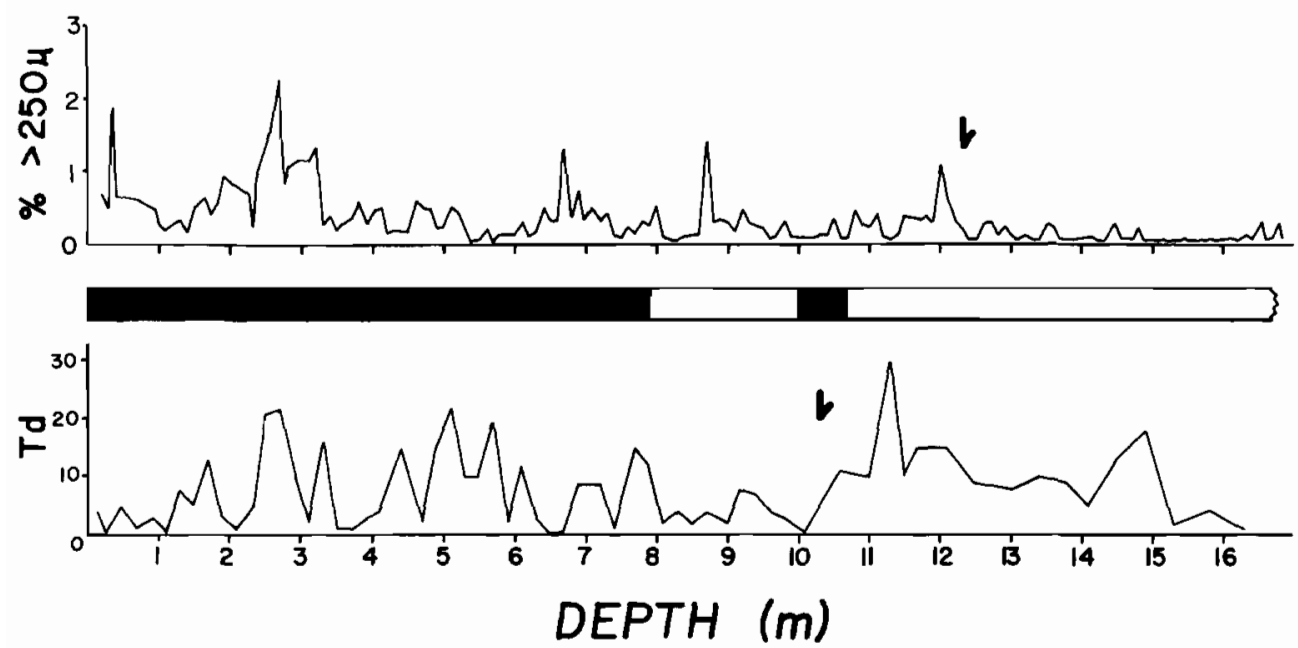

Figure 6. Percentage of the "glacial" fraction and Td values ( ratio of warm water to cold water diatom species; Donahue, 1970) in core V20-108. Magnetic stratigraphy

surface waters to the climatic changes. Kennett (1969) finds evidence of six climatic warmings in the last $.7 \mathrm{~m} . \mathrm{y}$. in subantarctic deep-sea cores. He recognizes a significant warm period in his Globorotalia inflata zone and dates it as occurring between 400,000 and 500,000 yrs ago. This marked warm interval in the Antarctic may bear some relationship to the period of low ice rafting and warmer surface water (based on diatom evidence) in the North Pacific between about 460,000 and 530,000 yrs ago.

Hays and others (1969) find eight carbonate cycles in the Brunhes series of the equatorial Pacific, and interpret them as representing eight major glacial fluctuations (after Arrhenius, 1952). A possible correlation between the two sequences is shown in Figure 7. The good time correlation of high carbonate zones and zones representing an increase in the intensity of ice rafting supports the hypothesis that high carbonate content zones in the equatorial Pacific are closely related to glaciations, at least within the Brunhes and probably in the Upper Matuyama.

Hays and others (1969) note that climatic curves derived by three different methods show five temperature minima in the last 400,000 yrs. These include the Globorotalia menardii abundance curve (Ericson and Wollin, 1968) and $0^{18}$ curves (Emiliani, 1966; Broecker and van Donk, 1970) from the Atlantic and Caribbean Oceans, and the carbonate curves from from Ninkovich and others (1966). Arrows indicate beginning of climatic deterioration as interpreted in this core from each parameter.

the equatorial Pacific (see Fig. 16, Hays and others, 1969). Examination of our ice-rafted abundance curves indicates that another climatic curve derived by a fourth method suggests five temperature minima in the last 400,000 yrs (see Fig. 3). However, there is little correspondence between the ice-rafted abundance curve from the North Pacific to the $G$. menardii abundance curve from the Atlantic (Ericson and Wollin, 1968) prior to 400,000 yrs B.P.

\section{COMPARISON WITH TERRESTRIAL SEQUENCES}

The correlation of the glacial sequence from deep-sea cores with the classic glacial stages of North America and Europe is difficult if not impossible in the absence of absolute dates in the type areas. The terrestrial record left by smaller glacial phases could easily be eradicated by succeeding larger glaciations. The possibility that each of the classic glaciations had several phases presents additional complications. The last peak of ice-rafted detritus can be correlated with the Wisconsin or Würm glaciation since this event is coincident in time with the generally accepted dates for the last glacial. The correlation of preceding glaciations is problematical. Several approaches are possible. One can simply count back four glacial cycles from the present and call that glaciation the Gunz or Nebraskan. This has been done in the past and 


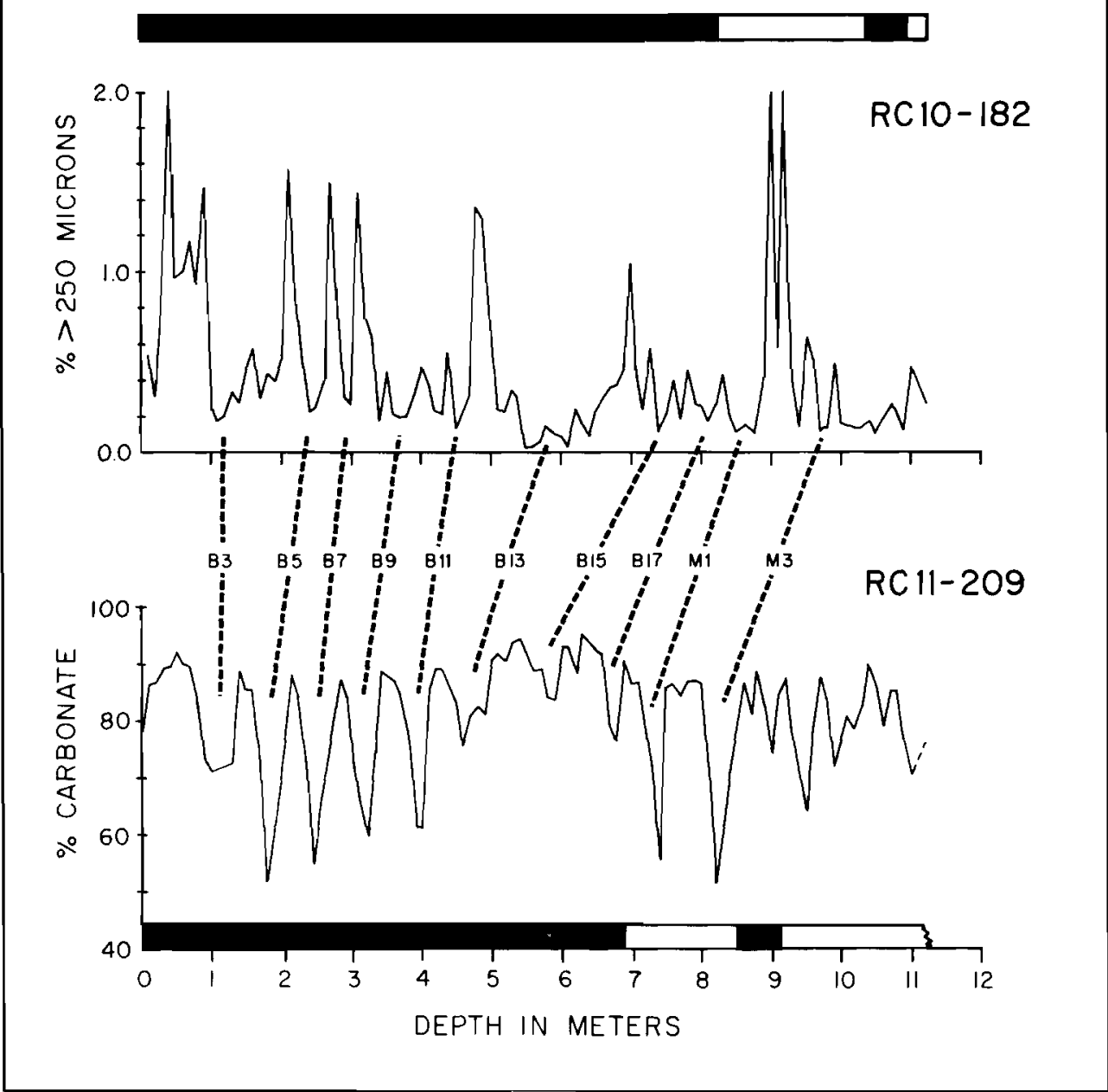

Figure 7. Possible correlation of carbonate cycles in equatorial Pacific to fluctuations in ice-rafted content in

leads to the so-called short time scale. Alternatively, one might pick the three largest preceding glacials, but it is exceedingly difficult to determine which glaciations were the most intense. Another approach would be to name the oldest glaciation the Nebraskan or Gunz, but since glaciation began in the Upper Miocene, this seems to be an unreasonable procedure.

The pronounced glacial maximum at around 750,000 yrs ago probably correlates with the Sherwin Till which underlies the Bishop Tuff in the Sierra Nevada, previously dated at 700,000 yrs ago (Dalrymple and others, 1965). Other useful dates from North America are not presently known to the writers.

In Europe, the Brunhes-Matuyama reversal the North Pacific.

boundary has been determined in two sedimentary sequences. It has been found in Cromerian sediments of the Netherlands by van Montfrans and Hospers (1969) and in the Cerveny Kopec loess sequence of Czechoslovakia by Bucha and others, (1969). Nine complete loess cycles have been shown to exist in the Cerveny Kopec loess deposits and are considered to represent nine glacial cycles by Kukla (1969). These cycles have been lettered $B$ through $J$ and the Brunhes-Matuyama boundary occurs in cycle $\mathrm{I}$, leaving one complete Matuyama glacial cycle and seven or eight cycles in the Brunhes epoch, representing the last 700,000 yrs.

In Japan, a paleomagnetic stratigraphy of Plio-Pleistocene series in Kinki and Tokai dis- 
tricts was determined from intercolated ash layers (Ishida and others, 1969). This magnetic stratigraphy was used to date cold and warm periods deduced from floral changes. The Gokenya cold age occurs between the base of the Brunhes and the top of the Jaramillo event and was dated at about $.80 \mathrm{~m} . \mathrm{y}$. ago. It seems reasonable to correlate Cerveny Kopec loess cycle $\mathrm{J}$ with the glacial event in the North Pacific at approximately $.75 \mathrm{~m}$.y. ago, which we have already shown probably correlates with the Sherwin Till of the Sierra Nevada range. Therefore, the Menapian glacial deposits of the Netherlands which underlie the Cromerian can be correlated with cycle J of the Czechoslovakian loess sequence on the basis of the magnetic correlation, and to all the other glacial sequences of this age mentioned above.

A suggested correlation of our marine glacial sequence to the classic terrestrial sequences is given in Figure 9. Glacial and interglacial terminology as used after Zeuner (1959) is a general compilation of terrestrial sequences from various places. Terrestrial correlations have been adapted from Flint (1957), Zeuner (1959) and Charlesworth (1957).

Three periods of intense ice rafting in the North Pacific can be correlated with some confidence to terrestrial events. The last glaciation has been dated as beginning approximately $80,000 \mathrm{yrs}$ ago, based on high sea level stands just prior to this date (Broecker and van Donk, 1970). The youngest zone of abundant detritus in our cores undoubtedly corresponds to this event. The second tie-in point is based on the reversal found in the Cromerian of the Netherlands (van Montfrans and Hospers, 1969). A geomagnetic field reversal has also been reported to have occurred in Upper Lower Pleistocene (Cromerian) marine clays from portions at two borehole cores drilled in East Anglia near Covehithe (Noltimier, 1967). If these reversals do in fact represent the BrunhesMatuyama boundary, then the Cromerian, considered to represent the Antepenultimate Interglacial, can be correlated with the general ice-rafted low around the Brunhes-Matuyama boundary in our cores. The third correlatable zone is the marked ice-rafted low between 460,000 and 530,000 yrs ago. Its character and position in time suggest a correspondence to what is termed the Penultimate or Great Interglacial by Zeuner (1959). A tuff of Volcano Bracciano in Italy which Blanc (1957) tentatively assigns to the late Mindel-Riss interglacial was dated at 430,000 yrs ago (Evernden and others, 1964). The age and correlation agree with our interpretation of the position of the Mindel-Riss interglacial.

On the basis of these three correlatable zones, we can infer the following correlation of glacial sequences. The Antepenultimate (Cromerian) Interglacial occurs between the early glacial (Gunz) and the Antepenultimate (Mindel) Glacial. Therefore, the ice-rafted peak at about $.75 \mathrm{~m} . y$. ago would correspond to the Gunz, and the split in this peak (see RCl1171) may correspond to the two phases of this glacial, (Zeuner, 1959). The three phases of the Donau may be represented by correlatable ice-rafted peaks at .95, 1.1, and $1.2 \mathrm{~m} . \mathrm{y}$. ago. The zone of ice-rafted detritus between the Brunhes-Matuyama boundary and the marked ice-rafted low at about 500,000 yrs ago is then correlated with the Antepenultimate Glacial (Mindel). The Antepenultimate Glacial (Mindel) has been thought to be the most extensive glacial by many authors and thus corresponds to a long period of extensive ice rafting in the North Pacific. The split in this event (see RC11171, V20-109) may correspond to the two phases of the Antepenultimate Glacial (Flint, 1957; Zeuner, 1959).

Correlation of the ice-rafted sequence above the marked low to terrestrial glacial sequences is difficult. The terrestrial sequences show at most three distinct glaciations since the Penultimate Interglacial, whereas the ice-rafted curves indicate a minimum of five zones of intense ice rafting. One possible correlation is presented in Figure 8.

If the classic four Alpine glaciations are equivalent to the four North American glaciations, then we may conclude on the basis of our correlations that the Sherwin Till is of Nebraskan age. It might also be noted that the Yarmouth is considered the longest American interglacial (Charlesworth, 1957, p. 974) and would correspond to the Penultimate of Great Interglacial (Mindel-Riss) of Europe, which is felt to be represented by the marked ice-rafted low of .5 m.y. ago.

The Cerveny Kopec loess sequence, representing about seven glacial cycles within the Brunhes, supports the idea of more than four classic glaciations, or suggests that phases within a glaciation are more important and distinct than previously thought.

\section{CONCLUSIONS}

1. A marked increase of ice-rafted material beginning at about 1.2 m.y. B.P. indicates a 


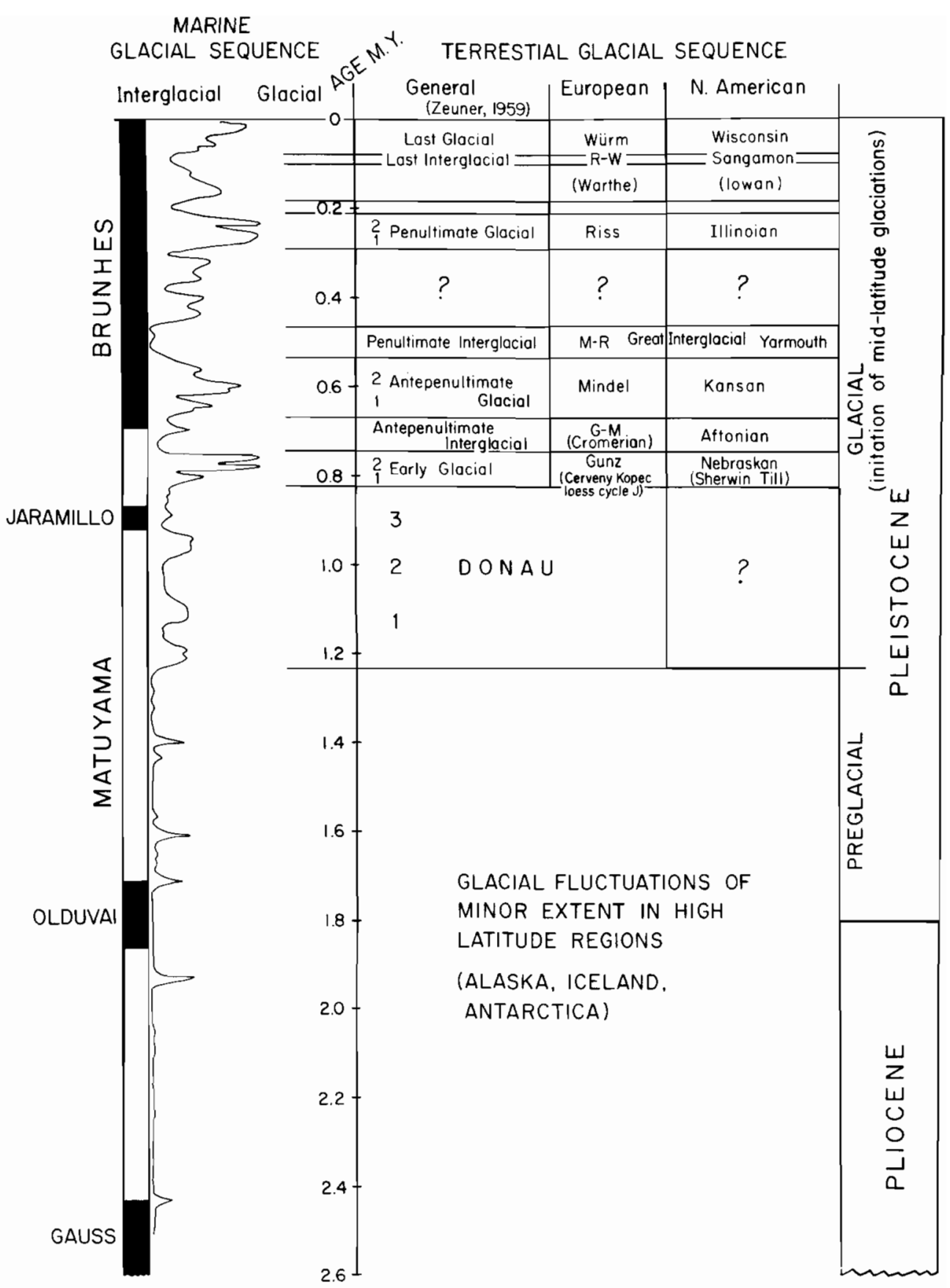

Figure 8. Correlation of terrestrial glacial sequences cific. Terrestrial sequences adapted from Zeuner (1959), with a generalized ice-rafting curve from the North $\mathrm{Pa}$ -

Flint (1957), and Charlesworth (1957). 
change to more glaciated conditions in the Cordilleran region of North America and the Kamchatka peninsula. A minimum of eleven periods of more intense ice rafting are present from 1.2 m.y. ago to the present, whereas only four such periods are present between $1.2 \mathrm{~m} . \mathrm{y}$. and 2.5 m.y. B.P. Faunal and floral evidence suggest a gradual cooling of North Pacific waters at about 1.2 m.y. B.P.

2. No change in the pattern of ice rafting occurs at the Olduvai event, the level of the Plio-Pleistocene boundary, but a significant change occurs at about 1.2 m.y. B.P. This suggests a division of the Pleistocene into preglacial and glacial parts where the former is 50 percent shorter than the latter (.6 and 1.2 m.y. ago, respectively).

3. The evidence from North Pacific cores indicates that the global cooling somewhere between the Jaramillo event and the BrunhesMatuyama boundary seen in the sediments of the world ocean coincides with more extensive glaciation on the continents and may mark the initiation of mid-latitude glaciations.

4. A minimum of six episodes of high iceberg frequency as represented by the debris which they drop are present in the Brunhes normal polarity series. The good time correlation within the Brunhes between maximums of glacial detritus in the North Pacific and carbonate cycles in the equatorial Pacific supports the hypothesis that high carbonate content within the Brunhes is associated with glaciations.

\section{ACKNOWLEDGMENTS}

The writers wish to thank Doctors J. Hays, W. Donn, W. Broecker and A. Kaneps for critically reviewing the manuscript and making many helpful suggestions. We are particularly grateful to the officers, crews and chief scientists aboard the R/V Vema and Robert Conrad for their important contributions to this program. We are also appreciative of the support provided by $\mathrm{R}$. Capo, the core curator at LamontDoherty Geological Observatory.

Miss Patricia Farrell examined the coarse fractions under the microscope and also took the electron micrograph pictures of the surface of sand grains. This assistance is greatly appreciated.

The work was supported by National Science Foundation Grants GA-11050 and GA-10635, and an Office of Naval Reseach Grant, N00014-67-A-0108-0004.

\section{REFERENCES CITED}

Arrhenius, G., 1952, Sediment cores from the East Pacific: Sweden Deep-Sea Expedition Rept., v. 5 , fasc. 1,89 p.

Bagnold, R. A., 1954, The physics of blown sand and desert dunes: London, Methuen and Co., $265 \mathrm{p}$.

Bandy, O. L., 1960, The geologic significance of coiling ratios in the Foraminifera Globigerina pachyderma (Ehrenberg): Jour. Paleontology, v. 34, p. 671-681.

Bandy, O. L., and Casey, R. E., 1969, Major late Cenozoic planktonic datum planes, Antarctic to the tropics: U. S. Antarctic Jour., v. 4, p. 170171.

Berggren, W. A., Phillips, J. D., Bertels, A., and Wall, D., 1967, Late Pliocene-Pleistocene stratigraphy in deep-sea cores from the south central North Atlantic: Nature, v. 216, p. 253-254.

Blanc, A. C., 1957, On the Pleistocene sequence of Rome, paleoecologic and archeologic correlations: Quaternaria, v. 4, p. 95-109.

Broecker, W. S., and van Donk, J., 1970, Insolation changes, ice volumes, and the $0^{18}$ record in deep-sea cores: Geophysics Space Phys. Rev., v. 8 , no. 1, p. 169 .

Bucha, V., Horacek, J., Koci, A., and Kukla, J., 1969, Die Paleomagnetische Messungen in dem Loss, in Demek, J., and Kukla, J., eds., Perglazialzone-Loss und Paleolithikum in der Tsehechoslowakei: Geogr. Anstalt der Tsch. Akademie der Wiss., Brno.

Charlesworth, J. K., 1957, The Quaternary era, v. 2: London, Edward Arnold Ltd.

Conolly, J. R., and Ewing, M., 1965a, Pleistocene glacial marine zones in North Atlantic deep-sea sediments: Nature, v. 208, p. 135-138.

$1965 \mathrm{~b}$, Ice rafted detritus as a climatic indicator in Antarctic deep-sea cores: Science, v. 150, p. 1822-1824.

- 1970, Ice-rafted detritus in Northwest Pacific deep-sea sediments: Geol. Soc. America Mem. 126 , p. 219.

Dalrymple, G. B., Cox, A., and Doell, R. R., 1965 , Potassium-argon age and paleomagnetism of the Bishop Tuff, California: Geol. Soc. America Bull., v. 76, p. 665-673.

Denton, G. H., and Armstrong, R. L., 1969, Miocene-Pliocene glaciations in southern Alaska: Am. Jour. Sci., v. 267, p. 1121-1142.

Donahue, J., 1970, Pleistocene diatoms as climaric indicators in North Pacific sediments: Geol. Soc. America Mem. 126, p. 121.

Emiliani, C., 1966, Paleotemperature analysis of Caribbean cores P6304-8 and P6304-9 and a generalized temperature curve for the past 425,000 years: Jour. Geology, v. 74, p. 109.

Ericson, D. B., 1959, Coiling direction of Globigerina pachyderma as a climatic index: Science, v. 130 , p. 219-220. 
Ericson, D. B., and Wollin, G., 1968, Pleistocene climates and chronology in deep-sea sediments: Science, v. 162, p. 1227-1234.

Evernden, J. F., Savage, D. E., Curtis, G. A., and James, G. T., 1964, Potassium-argon dates and Cenozoic mammalian chronology of North America: Am. Jour. Sci., v. 262, p. 145-198.

Flint, R. F., 1957, Glacial and Pleistocene geology: New York, John Wiley \& Sons, Inc., 553 p.

Griggs, G. B. and Kulm, L. D., 1969, Glacial marine sediments from the northeastern Pacific: Jour. Sed. Petrology, v. 39, p. 1142-1148.

Hays, J. D., and Opdyke, N. D., 1967, Antarctic Radiolaria, magnetic reversals, and climatic change: Science, v. 158, p. 1001-1011.

Hays, J. D., and Ninkovich, D.; 1970, North Pacific deep-sea ash chronology and age of present Aleutian underthrusting: Geol. Soc. America Mem. 126, p. 263.

Hays, J. D., Saito, T., Opdyke, N. D., and Burckle, L. H., 1969, Pliocene-Pleistocene sediments of the equatorial Pacific; their paleomagnetic, biostratigraphic, and climatic record: Geol. Soc. America Bull., v. 80, p. 1481-1514.

Horn, D. R., Delach, M. N., and Horn, B. M., 1969 , Distribution of volcanic ash layers and turbidites in the North Pacific: Geol. Soc. America Bull., v. 80, p. 1715-1724.

Ishida, S., Maenaka, K., and Tokoyama, T., 1969, Paleomagnetic chronology of volcanic ash of the Plio-Pleistocene series in Kinki District, Japan: Geol. Soc. Japan Jour., v. 75, p. 183-197.

Kennett, J. P., 1969, Foraminiferal studies of Southern Ocean deep-sea cores: Antarctic Jour., v. 4, p. 178.

Krinsley, D., and Margolis, S., 1969, A study of quartz and sand surface textures with the scanning electron microscope: New York Acad. Sci. Trans., v. 31, p. 457-477.

Kukla, J., 1969, The cause of the Holocene climate change: Geologie en Mijnbouw, v. 48/3, p 307-334.
Needham, H. D., Conolly, J. R., Ruddiman, F. A., and Bowles, F. A., 1969, Continental sediment in equatorial Atlantic ooze - a climatic record of the Pleistocene: Geol. Soc. America, Abs. with Programs for 1969, Pt. 7 (Ann. Mtg.), p. 158.

Ninkovich, D., Opdyke, N. D., Heezen, B. C., and Foster, J., 1966, Paleomagnetic stratigraphy, rates of deposition and tephrachronology in North Pacific deep-sea sediments: Earth and Planetary Sci. Letters, v. 1, p. 476-492.

Noltimier, H. C., 1967, Impregnation of weak sediment for paleomagnetic measurements: Earth and Planetary Sci. Letters, v. 2, p. 177-178.

Opdyke, N. D., and Foster, J. H., 1971, The paleomagnetism of cores in the North Pacific: Geol. Soc. America Mem. 126, p. 83.

Olson, R. K., and Goll, R., 1969, Biostratigraphy, Leg 5, Deep-Sea Drilling Project, in McManus, D. A., and others, Initial Reports of the DeepSea Drilling Project, v. 5: Washington, U. S. Government Printing Office, p. 557-567.

Selli, R., 1967, The Pliocene-Pleistocene boundary in Italian marine sections and its relationship to continental stratigraphy: Oceanog. Prog., v. 4, p. 67-86.

U. S. Navy Hydrographic Office, 1946, Ice atlas of Northern Hemisphere: U. S. Navy Hydrog. Office Pub. 550.

van Montfrans, H. M., and Hospers, J., 1969, A preliminary report on the stratigraphical position of the Matuyama-Brunhes geomagnetic reversal in the Quaternary sediments of the Netherlands: Geologie en Mijnbouw, v. 48, p. 565-572.

Zeuner, F. E., 1959, The Pleistocene period: London, Hutchinson Scientific and Technical, $447 \mathrm{p}$.

Manuscript Received by The Society february 11 , 1971

REVISED MANUSCRIPT RECEIVED MAY 11, 1971

LAMONT-DOHERTY GEOLOGICAL OBSERVATORY CONTRIBUTION No. 1661 